\begin{tabular}{|c|c|}
\hline 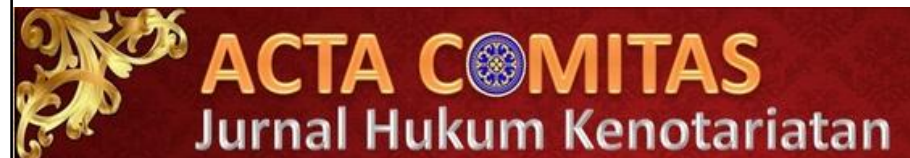 & $\begin{array}{l}\text { Vol } 4 \text { No } 2 \text { Agustus 2019 } \\
\text { e-ISSN: 2502-7573 | p-ISSN: 2502-8960 } \\
\text { Open Acces at: https://ojs.unud.ac.id/index.php/ActaComitas }\end{array}$ \\
\hline
\end{tabular}

\title{
KEBIJAKAN FORMULASI \\ PERTANGGUNGJAWABAN PIDANA \\ PENGGUNA JASA PROSTITUSI MELALUI MEDIA ONLINE
}

\author{
Alexander Imanuel Korassa Sonbai ${ }^{1}$ \\ Advokat, Drs. J. Korassa. S, SH., MH, Jln. Sekar Jepun VIII No. C/37, Gatot Subroto \\ Timur, Denpasar-Bali \\ E-mail : alexks12@ymail.com
}

\begin{tabular}{l}
\hline Info Artikel \\
\hline Masuk: \\
Diterima: \\
Terbit: \\
Keywords : \\
Formulation Policy, Criminal \\
Liability, Service User, Online \\
Prostitution \\
\\
\\
\\
\\
Corresponding Author: \\
Alexander Imanuel Korassa \\
Sonbai, E-mail: \\
alexks12@ymail.com \\
Kata kunci: \\
Kebijakan Formulasi, \\
Pertanggungjawaban Pidana, \\
Pengguna Jasa, Prostitusi Online \\
\end{tabular}

\begin{abstract}
The phenomenon of online prostitution became a hot issue in Indonesia. Online Prostitution Article 27 paragraph (1) Jo. Article 45 paragraph (1) of the ITE Law, Article 296 of the Criminal Code, Article 506 of the Criminal Code, Article 2 paragraph (1) of Law No. 21 of 2007 concerning Eradication of Crime in Trafficking in Persons, and Article 30 Jo. Article 4 paragraph (2) Law No. 44 of 2008 concerning Pornography. However, in the article has not set explicitly against online prostitution service users. The aim of this study was to elaborate on the user settings prostitution service through online media and forms of criminal responsibility prostitution service users through online media. The method used is a normative legal research. This type of approach is used, among others: statue approach, conceptual approach, and comparative approach. The results of the study indicate that the formulation policy criminal liability for online prostitution service users has not yet been regulated in Indonesian legislation, from the results of a comparison with Sweden (Sex Purchase Act) also regulates the criminal liability of users of online prostitution services and should the rules in the future refer to Swedish law (sex purchase act).
\end{abstract}

\footnotetext{
Abstrak

Fenomena prostitusi online menjadi suatu isu hangat di Indonesia. Prostitusi online Pasal 27 ayat (1) Jo. Pasal 45 ayat (1) UU ITE, Pasal 296 KUHP, Pasal 506 KUHP, Pasal 2 ayat (1) UU No. 21 tahun 2007 tentang Pemberantasan Tindak Pidana Perdagangan Orang, dan Pasal 30 Jo. Pasal 4 ayat (2) UU No. 44 tahun 2008 tentang Pornografi. Namun, dalam pasal tersebut belum mengatur secara eksplisit terhadap pengguna jasa prostitusi online. Tujuan
} 
DOI :

xxxxxxx

\section{Pendahuluan}

Zaman yang kian mengalami kemajuan serta melaksanakan perubahan-perubahan kearah pembaharuan. Di dalam hal ini teknologi juga meniru kemajuan zaman tersebut, kemajuan teknologi merambah terhadap bidang komunikasi, sampai-sampai gaya akses berkomunikasi mengalami peralihan yang tajam. Seseorang makin gampang berkomunikasi bersama orang lain dengan cakupan yang luas. ${ }^{1}$

Pembangunan nasional ialah sebuah metode yang berkesinambungan yang wajib terus menerus peka dalam beragam dinamika yang berlaku didalam masyarakat. Penggunaan informasi teknologi, perangkat serta komunikasi sudah memperbarui sikap masyarakat serta kebudayaan manusia secara keseluruhan. Perubahan informasi teknologi serta komunikasi sudah juga membawa dampak hubungan dunia menjadi tidak dengan batasan serta membawa dampak perubahan social, ekonomi serta budaya secara istimewa berjalan dengan cepat. ${ }^{2}$

Pada kondisi yang terbuka serta kebebasan sekarang ini, siapapun mempunyai kebebasan ruang yang luas agar dapat menuangkan beragam macam idenya ataupun pandangannya dalam ruang publik lewat berbagai macam sosial media antara lain : Mozila Firefox maupun Google, tetapi yang sangat diminati dikomunitas para pemakai sosial media antara lain Twitter, Instagram, BBM, Facebook, WhatsApp,dan lain sebagainya.

Secara tertentu, kemajuan teknologi komputer serta internet membagikan konotasi yang penting akan pengaturan ataupun pembuatan peraturan di dalam kawasan cyber

1 Febriharini, M. P. (2016). Eksistensi Hak Atas Kekayaan Intelektual terhadap Hukum Siber. Serat Acitya, 5(1), 15. h. 15.

2 Illah, I. A., Waty, N., \& Alwan, A. (2014). Prostitusi Online Dilihat Dari Instrumen Hukum Undang-Undang Nomor 11 Tahun 2008 Tentang Informasi dan Transaksi Elektronik. Jurnal Mahupiki, 2(1). h.4. 
maupun hukum cyber dan pada kemajuan kriminalitas di dalam dunia virtual. ${ }^{3}$ Satusatunya akibat buruk yang kadang-kadang timbul ialah makin gampangnya berhubungan serta beralih berita dengan menggunakan sosial media antar sesama pemakai adalah jual-beli prostiusi online.

Perkembangan internet yang semakin berkembang pesat ibarat bagai uang yang memiliki dua sisi mata, di satu sisi memiliki dampak yang efektif untuk mempermudah ketika akan berinteraksi antar sesama manusia, beralih informasi lalu mengetahui perkembangan teknologi masa kini. Sedangkan dalam perspektif lain juga menyimpan dampak minus contohnya video pornografi dan banyak perbuatan asusila lainnya yang dilakukan melalui internet. Semakin berkembangnya teknologi internet, maka muncul kejahatan yang dilakukan melalui jaringan internet yang mana dikenal dengan kejahatan dalam dunia maya. Bagian dari kejahatan tersebut yakni prostitusi yang dilakukan dengan internet atau dapat dikatakan sebagai pelacuran online. ${ }^{4}$

Makin berkembangnya teknologi informasi tentang internet yang semakin pesat maka semakin besar saja kejahatan dalam media internet yang akan timbul. Salah satu kejahatan yang di lakukan dengan memanfaatkan kecangihan teknologi adalah prostitusi online. Kejahatan tersebut merupakan persoalan hangat yang memikat atensi masyarakat hingga saat ini. Prostitusi online merupakan kegiatan menjual tubuh maupun pelayanan terhadap seseorang buat melakukan melakukan tindakan sensual demi imbalan berupa honorarium sebagaimana yang telah disepakatinya. Prostitusi merupakan kegiatan yang sangat bertentangan dengan nilai moral dan nilai kesusilaan. Kegiatan prostitusi sudah ada sejak dulu dan dalam pandangan masyarakat dikenal sebagai penyakit. Hal yang mendukung kegiatan ini tidak lain untuk menemukan kebahagiaan bagi individu ataupun pengguna jasa yang memperisapkan servis ini.

Melihat perubahan teknologi yang makin berubah pesat sekarang ini, media sosial sekarang bukan hanya sebagai sarana untuk mencari teman ataupun beralih berita, melainkan dapat menjadi sarana untuk berhubungan, dapat jadi penghubung yang efektif demi melangsungkan sebuah bisnis, servis ataupun akar sosialisasi yang sekarang telah enggak heran lagi, digunakan sebagai sarana buat melaksanakan tindakan illegal. Sosial media saat ini acap kali digunakan sebagai sarana paling tepat buat melengkapi incaran ataupun mangsa ketika melaksanakan jual-beli bisnis prostitusi online. Lebih- lebih lagi banyaknya prostitusi online yang dilakukan secara online, terlihat para perempuan ataupun pria yang menggeluti pekerjaan prostitusi online saat ini memakai sarana sosial media yang telah menjadi suatu siasat demi menjual tubuhnya pada saat memperoleh pelanggan.

3 Sitompul, J, (2012), Cyberspace, Cybercrimes, Cyberlaw Tinjauan Aspek Hukum Pidana, Jakarta: Tatanusa, h. 26.

4 Maulidya, R. (2017). Pertanggungjawaban Pidana Pekerja Seks Komersial Dalam Tindak Pidana Prostitusi Secara Online Berdasarkan Undang Undang Nomor 11 Tahun 2008 Tentang Informasi Dan Transaksi Elektronik Di Polresta Pekanbaru. Jurnal Online Mahasiswa (JOM) Bidang Ilmu Hukum, 3(2), 1-15. h. 2 
Beberapa waktu yang lalu telah terjadi kasus yang cukup hangat tentang prostitusi online yakni kasus prostitusi online yang menjerat artis terkenal di Indonesia yang bernama Vanessa Angel. Vanessa Angel di dakwa dengan Pasal 27 ayat (1) UU ITE dengan alasan Vanessa Angel secara langsung mengeksploitasi dirinya ke mucikari. ${ }^{5}$ Sedangkan, terhadap pengguna jasa Vanessa Angel yang bernama Rian Subroto sendiri tidak di jerat hukum.

Prostitusi online di Indonesia diatur dalam beberapa aturan antara lain : Pasal 27 ayat (1) Jo. Pasal 45 ayat (1) UU ITE, Pasal 296 KUHP, Pasal 506 KUHP, Pasal 2 ayat (1) UU No. 21 tahun 2007 tentang Pemberantasan Tindak Pidana Perdagangan Orang, dan Pasal 30 Jo. Pasal 4 ayat (2) UU No. 44 tahun 2008 tentang Pornografi. Keseluruhan aturan-aturan tersebut hanya mengenakan pertanggungjawaban pidana terhadap penyedia jasa prostitusi sedangkan terhadap penggunajasa prostitusi online tidak dapat dikenakan pertanggungjawaban pidana. Berdasarkan hal tersebut, Penulis menemukan kekosongan norma hukum untuk menjerat pengguna jasa prostitusi online karena itu sudah seharusnya diadakan pembaharuan hukum pidana agar dapat mengatur pengguna jasa prostitusi online yang sejalan dengan perkembangan kebutuhan masyarakat terhadap delik kesusilaan dalam bidang kejahatan seksual karena undang-undang yang legal sekarang ini telah tidak sesuai dengan perkembangan zaman serta nilai yang ada dan berkembang dalam masyarakat.

Pengguna jasa prostitusi boleh dikatakan sebagai orang atau kelompok orang yang bebas, artinya belum terikat pada aturan hukum positif. Tinjauan menurut perspektif hukum positif menjabarkan prostitusi kearah yang belum lengkap, artinya dalam hukum positif hanya mengatur ketentuan terhadap mucikari dan PSK. Seperti dilansir dalam sebuah media internet yaitu aksi pelacuran atau prostitusi online kenyataannya disukai golongan pria Indonesia. Tidak dapat dipungkiri tentang modus kejahatan yang bisa terjadi terhadap prostitusi apabila norma hukum belum mengaturnya.

Beranjak dari alasan-alasan tersebut diatas, maka dapat di rumusankan beberapa permasalahan yakni pertama, kebijakan formulasi pertanggungjawaban pidana pengguna jasa prostitusi melalui media online saat ini (ius constitutum)? dan kebijakan formulasi pertanggungjawaban pidana pengguna jasa prostitusi melalui media online perspektif pada masa yang akan datang (ius constituendum)? Penulisan ini bertujuan untuk menganalisis kebijakan formulasi pertanggungjawaban pidana pengguna jasa prostitusi melalui media online saat ini (ius constitutum) dan kebijakan formulasi pertanggungjawaban pidana pengguna jasa prostitusi melalui media online pada masa yang akan datang (ius constituendum).

Diperoleh beberapa penelitian dahulu yang mana telah mengupas mengenai prostitusi online antara lain: sebuah riset atau studi yang dilaksanakan Arya

5 Indonesia, CNN, (2019). Vanessa Angel Jadi Tersangka Kasus Prostitusi Online. Url: https://www.cnnindonesia.com/nasional/20190116163019-12-361299/vanessa-angel-jaditersangka-kasus-prostitusi-online, diakses 21 Mei 2019 
Mahardika Pradana di tahun 2015.6 Hasil dari studi atau risetnya adalah bagianbagian tindakan ataupun perbuatan yang tersusun di dalam aturan undang-undang yang melengkapi seluruh bagian-bagian dari tindakan prostitusi atau pelacuran hanya diatur dalam PERDA tidak dalam KUHP. Akan tetapi salah satu unsur dari prostitusinya, yakni hubungan intim disusun menjadi delik berdasarkan (KUHP), walaupun tidak secara spesifik menyelesaikan terhadap tindakan prostitusi atau pelacurannya, akan tetapi melalui aturan yang mengelompokkan tentang hubungan intim yang illegal di dalam KUHP, dapat memidana para prostitusi. Jadi, dengan adanya pemidanaan terhadap para prostitusi, hingga bisa disebut bahwa prostitusi ataupun pelacuran itu adalah delik. Penelitian lain yang membahas pengguna jasa prostitusi online adalah penelitian yang dilakukan oleh Miftah Raharjo dan Lilik Mulyadi pada tahun 2017.7 Hasil dari penelitian tersebut untu saat ini secara khusus belum ada aturan yang secara spesifik mengatur tindak pidana prostitusi online. Karenanya agar dapat pelaku prostitusi online di jerat hukum digunakan Pasal 296 KUHP, Pasal 506 KUHP, Pasal 2 ayat (1) UU No. 21 tahun 2007 tentang Pemberantasan Tindak Pidana Perdagangan Orang, Pasal 27 ayat (1) UU No. 11 tahun 2008 (UU ITE), Pasal 30 jo Pasal 4 ayat (2) UU No. 44 tahun 2008 tentang Pornografi. Putusan hakim No: 310/Pid.Sus/2016/PN.Yyk sudah sesuai karena telah memenuhi unsur-unsur dalam Pasal 27 ayat (1) juncto Pasal 45 UU ITE.

\section{Metode Penelitian}

Tipe penelitian di dalam penelitian ialah penelitian hukum normatif. Penelitian hukum normatif dikatakan sebagai studi hukum yang memfokuskan ataupun mengkaji berupa aturan undang-undang. Penelitian hukum normatif mendudukan hukum bagaikan sistem norma. Sistem norma nan dikehendaki antara lain yaitu : asas hukum atau dasar hukum, nilai, ajaran dari aturan undang-undang, vonis pengadilan, perjanjian serta aliran. Jenis pendekatan yang dipakai didalam penulisan ini adalah pendekatan perundang-undangan (the statue approach), pendekatan konseptual (conceptual approach), dan pendekatan perbandingan (comparative approach). Dalam pendekatan perundang-undangan (the statue approach) penulis akan meneliti aturan undang-undang yang sah atau legal, dalam pendekatan konseptual (conceptual approach) setelah Penulis mendalami atau mengeksplorasi pendapat-pendapat serta ajaran-ajaran ilmu hukum, penulis hendak mendapatkan gagasan-gagasan yang dapat menyampaikan pemahaman tentang hukum, konsepsikonsepsi hukum serta dasar-dasar hukum signifikan atas permasalahan yang akan dihadapkan dan dalam pendekatan perbandingan (comparative approach) Penulis akan melakukan kajian perbandingan sistem hukum dengan negara asing. Bahan hukum

\footnotetext{
6 Pradana, A. M. (2015). Tinjauan Hukum Pidana Terhadap Prostitusi dan Pertanggungjawaban Pidana Para Pihak yang Terlibat dalam Prostitusi. Jurnal Hukum \& Pembangunan, 45(2), 276-307. h. 307

7 Raharjo, M., \& Mulyaddii, L. (2017). Penerapan Sanksi Pidana Terhadap Pelaku Prostitusi Online Di Yogyakarta. Kajian Hasil Penelitian Hukum, 1(2), 16-26. h. 23-24
} 
yang digunakan dalam penulisan ini adalah bahan hukum yang menyangkut serta sesuai dengan permasalahan penelitian ini.

\section{Hasil dan Pembahasan}

\subsection{Kebijakan Formulasi Pertanggungjawaban Pidana Pengguna Jasa Prostitusi Melalui Media Online Saat Ini (Ius Constitutum)}

Menurut Barda Nawawi Arief kebijakan penegakan hukum pidana merupakan serangkaian proses yang terdiri dari tiga tahap kebijakan antara lain sebagai berikut

1) Kebijakan legislatif atau formulatif;

2) Kebijakan yudikatif; dan

3) Kebijakan eksekutif atau administratif

Selanjutnya, dalam ketiga tahapan kebijakan penegakan hukum pidana tersebut didalamnya mengandung tiga kekuasaan atau kewenangan, yakni kekuasaan legislatif/formulatif dalam menetapkan atau merumuskan perbuatan apa yang dapat dipidana dan sanksi apa yang dapat dikenakan; kekuasaan yudikatif/aplikatif dalam penerapan hukum pidana; dan kekuasaan eksekutif atau administratif dalam melaksanakan hukum pidana. ${ }^{8}$

Kebijakan formulasi hukum pidana didasarkan pada ketentuan-ketentuan dalam konsideran yang terdapat dalam suatu peraturan perundang-undangan dari yang sudah diundangkan merupakan langkah awal dalam menentukan kebijakan baru atau mereformulasikan kebijakankebijakan yang secara sadar dilakukan oleh institusi legislatif bersama dengan eksekutif yang kemudian ditegakkan oleh lembaga yudikatif. Pengaturan kebijakan hukum pidana diformulasikan untuk menanggulangi suatu kejahatan atau tindak pidana untuk mencapai perlindungan dan kesejahteraan masyarakat. ${ }^{9}$

Di dalam memahami tentang pelacuran atau prostitusi online, peraturan pada setiap negara saling berlainan dalam menanggapinya, ada Negara yang menganggap prostitusi online merupakan delik, tetapi terdapat juga Negara yang memiliki sikap diam dengan sebagian pengkhususan, Indonesia termasuk yang bersikap diam dengan beberapa pengkhususan. Akar dari ketentuan pidana di Indonesia yakni Kitab Undang-Undang Hukum Pidana atau yang dikenal dengan Kitab UndangUndang Hukum Pidana (KUHP) seperti apa yang dikatakan sebagai ketentuan pidana bersifat umum. Selanjutnya, ditemukan juga ketentuan pidana bersifat spesifik sebagai halnya yang terdapat di beragam aturan undang-undang UU ITE, UU Pemberantasan Tindak Pidana Perdagangan Orang, dan UU Pornografi.

8 Satriana, I. M. W. C. (2013). Kebijakan Formulasi Keadilan Restoratif dalam Sistem Peradilan Pidana Anak. Jurnal Magister Hukum Udayana (Udayana Master Law Journal), 2(3). h. 9

9 Wirya, A. (2015). Kebijakan Formulasi Hukum Pidana Dalam Penanggulangan Tindak Pidana Kehutanan. Jurnal IUS Kajian Hukum dan Keadilan, 3(1). h. 25 
Pada bagian pertama dalam tulisan ini telah dijelaskan bahwa kebijakan formulasi pertanggungjawaban pidana pengguna jasa prostitusi online saat ini belum di atur dalam peraturan perundang-undangan Indonesia. Analisis pertanggungjawaban pidana dari segi teori bisa dijelaskan bahwa pertanggungjawaban pidana bisa berlaku ketika sebelumnya seorang sudah melakukan delik. Dalam bagian suatu uraian dalam peraturan dapat di nyatakan bahwa ada tiadanya pidana di putuskan berdasarkan aturan hukum yang berlaku atau sah, yang di tafsirkan bahwa tiada pertanggungjawaban pidana tanpa aturan hukum yang sah. Mengenai pengguna jasa prostitusi tidak bisa dijatuhkan pidana mengingat elemen-elemen tersebut sudah menggambarkan secara jelas lemahnya hukum pidana saat ini.

Kebijakan pemerintah Indonesia saat ini tidak secara jelas dan tegas melarang praktek prostitusi, karena aturan yang mengatur tentang delik prostitusi online tiada mengatur syarat tentang sanksi hukum terhadap pengguna jasa prostitusi online, sehingga dengan demikian, pengguna jasa prostitusi online tiada satupun bisa dipertanggunggjawabkan secara hukum, serta para pengguna jasa yang ingin menggunakan PSK juga dapat dengan bebas tanpa takut terjerat sanksi hukum pidana. Melihat dari berbagai undang-undang yang berlaku saat ini tidak resmi spesifik untuk menjaring serta memberantas usaha prostitusi online, tiada satupun aturan yang mengatur tentang pengguna jasa prostitusi online, maka pengguna jasa prostitusi online itu tidak bisa dikenakan pertanggungjawaban pidana serta dijerat secara hukum.

\subsection{Kebijakan Formulasi Pengguna Jasa Prostitusi Melalui Media Online Pada Masa Yang Akan Datang (Ius Constituendum)}

Hukum pidana memandang konsepsi tentang "pertanggungjawaban" ialah konsepsi esensial yang diketahui melalui ajaran kesalahan. Dalam bahasa latinnya ajaran kesalahan diketahui melalui istilah mens rea. Ajaran menss rea didasarkan kepada suatu perilaku tiada membuat seseorang bersalah terkecuali apabila pemikiran seseorang tersebut tidak baik. Di dalam bahassa Inggris ajaran itu disusun melalui an acnt does not make a person guilty, unless the mind is legally blameworthy. Berlandaskan dasar yang termaktub, terdapat beberapa persyaratan yang wajib dipenuhi agar seseorang termaktub bisa di pidana, antara lain terdapat perbuatan pidana dan jiwa yang jahat.

Bahwa pertanggungjawaban pidana diartikan menjadi diteruskannya celaan yang objektif yang terdapat atas perbuatan pidana serta secara subjetif terpenuhiya persyaratan agar bisa di jatuhkan pidana mengingat perilakunya tersebut. Arti celaan objektif adalah perilaku yang dilaksanakan oleh individu jelas menggambarkan suatu perilaku yang terlarang. Melawan hukum formil ataupun melawan hukum materil. Sebaliknya, walaupun perilaku terlarang tersebut sudah dilaksanakan oleh individu, tetapi bila individu tersebut tiada bisa dicela mengingat di dalam diri individu tersebut tiada ada kesalahan, dengan demikian pertanggungjawaban pidana tiada barangkali ada. Agar bisa mengetahui apakah 
seseorang bisa dimintakan pertanggungjawaban pidana yang harus dibuktikan ialah ada tiadanya perbuatan pidana atau kesalahan yang dapat diancam berdasarkan hukum pidana. ${ }^{10}$ Mengenai pertanggungjawaban pidana, kesalahan harus mutlak ada dalam diri pelaku agar dapat dimintakannya pertanggungjawaban pidana dari si pelaku tindak pidana. ${ }^{11}$

Chairul Huda mengatakan bahwa pangkal dari adanya tindak pidana ialah dasar legalitas, sebaliknya dasar bisa dijatuhkannya pidana kepada pembuat tindak pidana ialah dasar kesalahan. Hal tersebut mengartikan pembuat tindak pidana cuma bisa dijatuhkan hukuman apabila memiliki kesalahan ketika dalam melaksanakan tindak pidana itu. Bilamana suatu individu dinyatakan memiliki kesalahan menyangkut masalah pertanggungjawaban pidana. Karenanya, pertanggungjawaban pidana ialah pertanggungjawaban orang pada tindak pidana yang telah dilaksanakannya. Secara tegas, yang dipertanggungjawabkan orang tersebut ialah tindak pidana yang dilaksanakannya. Berlakunya pertanggungjawaban pidana lantaran sudah terdapat adanya tindak pidana yang dilaksanakan individu tersebut. Pertanggungjawaban pidana atas dasarnya ialah satu metode yang dibentuk oleh hukum pidana demi reaksi kepada pelanggaran berdasarkan "kesepakatan menolak" suatu perilaku tertenttu. ${ }^{12}$

Mengenai elemen-elemen di dalam pertanggungjawaban pidana, karenanya pelaku delik bisa dinyatakan sanggup bertanggung jawab antara lain:

a. Harus ada tindak pidana

elemen perbuatan ialah bagian dari unsur utama pertanggungjawaban pidana, sebab seseorang tiada bisa di jatuhkan pidana bila tidak melaksanakan suatu perbuatan yang mana perbuatan yang dilaksanakan tersebut ialah perbuatan yang tidak sah berdasarkan undang-undang sebagaimana sesuai sama dasar legalitas yang di yakini. Dasar legalitas memiliki makna tiada suatu perilaku dapat di jatuhkan pidana bila mana undang-undang tersebut belum mengaturnya.

b. Kesalahan

Kesalahan dalam istilah asing dikatakan schhuld. Schhuld ialah kondisi psikologi seseorang yang bertalian bersama perilaku yang di lakukannya secara sedemikian bentuknya akibatnya berlandaskan kondisi termaktub, maka perilaku pelaku bisa di cela atas dasar perilakunya. Kesalahan tersebut terbagi menjadi dua yakni: kesengajaan (baik itu selaku maksud serta selaku tujuan) serta kealpaan atau lalai.

10 Wirasasmita, E. A. (2018). Pertanggung Jawaban Pidana terhadap Perawat Maternitas yang Menghilangkan Identitas Seorang Bayi di Rumah Sakit. Jurnal Magister Hukum Udayana (Udayana Master Law Journal), 7(2), 177-189. h. 181

11 Suendra, D. L. O. (2015). Pertanggungjawaban Pidana Koperasi dalam Tindak Pidana Melakukan Kegiatan Perbankan tanpa Ijin. Jurnal Magister Hukum Udayana (Udayana Master Law Journal), 4(2). h. 356

12 Huda, C, (2006), Dari Tiada Pidana Tanpa Kesalahan Menuju Kepada Tiada Pidana Pertanggungjawaban Pidana Tanpa Kesalahan, Cet. Kedua, Jakarta: Kencana, h. 68. 
c. Memiliki kapasitas bertanggungjawab

Kapasitas bertanggungjawab senantiasa bertalian bersama kondisi psycis pembuat. Kapasitas bertanggungjawab tersebut senantiasa disambungkan bersama pertanggungjawaban pidana, hal tersebut yang membuat kapasitas bertanggungjawab menjadi satu diantara elemen pertanggungjawaban pidana. Kapasitas bertanggungjawab ialah akar agar bisa memutuskan penjatuhan pidana terhadap pembuat. Kapasitas bertanggungjawab tersebut wajib di buktikan ada tiadanya oleh hakim, sebab itu bila seseorang tersebut tidak mempunyai kapasitas bertanggungjawab hal tersebut menjadi akar tidak di pertangungjawabkannya pembuat, maknanya pembuat tindak pidana tidak bisa di pidana dari suatu kasus tindak pidana.

d. Tiada dalih pemaaf

Dalih Pemaaf ialah dalih yang menghapuskan kesalahan atas pelaku suatu tindak pidana, sebaliknya perilakunya tentu melawan hukum. Karenanya, di dalam alasan pemaaf di liat berdasarkan pada sisi pihak pelakunya contohnya, karena pelakunya tidak sempurna akalnya (gila) maka tidak bisa mempertanggungjawabkan perilakunya tersebut.

Menurut pandangan monistis delik merupakan suatu persyaratan agar dapat di jatuhi suatu hukuman, berdasarkan hal tersebut maka elemen-elemen delik mencakup elemen perilaku melanggar hukum dan elemen pertanggungjawaban pidana. Sedangkan menurut dualistis satu perilaku dikategorikan menjadi suatu delik bila perilaku itu mengandung sifat melanggar hukum ataupun melengkapi rumusan undang-undang. Pandangan monistis serta dualistis termaktub merupakan teori-teori yang membahas mengenai apa yang diucapkan sebagai delik maka lebih menyimpan arti di tempat akademis, tidak mengenai persyaratan agar bisa di jatuhkan hukuman.

Mengenai persyaratan agar dapat di jatuhkan hukuman, susunan yang teratur dalam hukum pidana Indonesia berpedoman atas dasar legalitas dan dasar culpabilitas. Dalam dasar culpabilitas hukuman hanya bisa di terapkan bila pelaku tersebut mempunyai kesalahan. Dasar culpabilitas dan asas legalitas terjadi secara berbarengan, sampai- sampai persyaratan yang dideriviasi dari padanya terjadi juga secarra kumulatif. Berdasarkan hal tersebut, sanksi hukum bisa di jatuhi apabila dua elemen itu membuktikan secara legal serta kredibel atau terpercaya, yaitu perilaku pelaku mengandung sifat melawan hukum serta dalam dirinya pelaku terdapat kesalahan. Kesalahan di dalam makna tatanan kesalahan bisa di maknai sebagai kesalahan di dalam pengertian hukum, yang antara lain berbentuk kesengajaan, serta lalai.

Peraturan perundang-undangan Indonesia yang berlaku saat ini belum diatur sebuah gagasan terhadap di perlukannya legislasi yang mengatur tentang prostitusi secara spesifik terhadap pengguna jasa prostitusi online sehingga buat menelah permasalahan ini diperlukan landasan teoritis yakni teori kebijakan hukum pidana atau dalam bahasa Inggris penal policy. Penal policy pada dasarnya atau esensinya menggambarkan suatu cara buat melahirkan atau membuat aturan undang-undang 
pidana serasi sama kondisi sekarang ini (ius constitutum) dan di masa depan (ius constituendum). Penal policy tidak berbeda sedikitpun bersama pembaharuan hukum pidana di dalam artian sempit, sebab salaku satu sistem, hukum terdiri atas adat kebiasaan, susunan, dan isi atau pokok hukum. ${ }^{13}$ Inti dari penal reform ialah upaya untuk memperbaharui substansi hukum.

Berlandaskan pada sisi pendekatan kebijakan sehingga pengaturan pada pengguna jasa prostitusi online tiada bisa dilepaskan dari harus adanya perbaikan atau restorasi pada isi hukum yang dalam aturan undang-undang yang berlaku saat ini. Terhadap hal tersebut dapat dilakukan studi perbandingan dengan Negara asing. Sebagai materi perbandingan, Indonesia bisa mempelajari aturan hukum di Negara Swedia (Sex Purchase Act) pada 1 januari tahun 1999 dimana pemerintah Swedia mengkriminalisasikan prostitusi dan memidakan pelanggannya (pengguna jasa), tidak pekerja seksnya. Sebaliknya untuk pekerja seksnya, pemerintah memberikan santunan agar bisa mengakhiri pekerjaannya tersebut.14 Agar kedepannya pengguna jasa prostitusi online bisa dijerat menurut hukum. Maka dalam perspektif studi komparatif Indonesia dapat menjadikan negara Swedia sebagai materi perbandingan, Indonesia bisa mempelajari aturan hukum di negara Swedia (Sex Purchase Act) pada 1 januari tahun 1999 dimana pemerintah Swedia mengkriminalisasikan prostitusi dan memidakan pelanggannya (pengguna jasa), tidak pekerja seksnya. Sebaliknya untuk pekerja seksnya, pemerintah memberikan santunan agar bisa mengakhiri pekerjaannya tersebut

\section{Kesimpulan}

Kebijakan formulasi pertanggungjawaban pidana pengguna jasa prostitusi online saat ini belum di atur dalam peraturan perundang-undangan Indonesia. Kebijakan pemerintah Indonesia saat ini tidak secara jelas dan tegas melarang praktek prostitusi, karena aturan yang mengatur tentang delik prostitusi online tiada mengatur syarat tentang sanksi hukum terhadap pengguna jasa prostitusi online, sehingga dengan demikian, pengguna jasa prostitusi online tiada satupun bisa dipertanggunggjawabkan secara hukum, serta para pengguna jasa yang ingin menggunakan PSK juga dapat dengan bebas tanpa takut terjerat sanksi hukum pidana.

Pada sisi pendekatan kebijakan sehingga pengaturan pada pengguna jasa prostitusi online tiada bisa dilepaskan dari harus adanya perbaikan atau restorasi pada isi hukum yang dalam aturan undang-undang yang berlaku saat ini. Terhadap hal tersebut dapat dilakukan studi perbandingan dengan Negara asing. Sebagai materi

13 Silaban, F. E. S., Erwina, L., \& Mulyadi, M. (2013). Kebijakan Hukum Pidana Terhadap Pengaturan Tindak Pidana Narkotika Di Indonesia. Jurnal Mahupiki, 1(1). h. 7

14 Amalia, M. (2018). Analisis Terhadap Tindak Pidana Prostitusi Dihubungkan Dengan Etika Moral Serta Upaya Penanggulangan Di Kawasan Cisarua Kampung Arab. Jurnal Hukum Mimbar Justitia, 2(2), 861-880. h. 876. 
perbandingan, Indonesia bisa mempelajari aturan hukum di Negara Swedia (Sex Purchase Act) pada 1 januari tahun 1999 dimana pemerintah Swedia mengkriminalisasikan prostitusi dan memidakan pelanggannya (pengguna jasa), tidak pekerja seksnya. Sebaliknya untuk pekerja seksnya, pemerintah memberikan santunan agar bisa mengakhiri pekerjaannya tersebut

\section{Daftar Pustaka / Daftar Referensi}

\section{Buku}

Huda, C, 2011, Dari Tiada Pidana Tanpa Kesalahan menuju kepada Tiada Pertanggungjawaban Pidana Tanpa Kesalahan, Jakarta: Kencana Prenedia Media Group.

Sitompul, J, (2012), Cyberspace, Cybercrimes, Cyberlaw Tinjauan Aspek Hukum Pidana, Jakarta: Tatanusa.

\section{Jurnal}

Amalia, M. (2018). Analisis Terhadap Tindak Pidana Prostitusi Dihubungkan Dengan Etika Moral Serta Upaya Penanggulangan Di Kawasan Cisarua Kampung Arab. Jurnal Hukum Mimbar Justitia, 2(2), 861-880.

Anindia, I. A., \& Sularto, R. B. (2019). Kebijakan Hukum Pidana Dalam Upaya Penanggulangan Prostitusi Sebagai Pembaharuan Hukum Pidana. Jurnal Pembangunan Hukum Indonesia, 1(1), 18-30.

Febriharini, M. P. (2016). Eksistensi Hak Atas Kekayaan Intelektual terhadap Hukum Siber. Serat Acitya, 5(1), 15.

Illah, I. A., Waty, N., \& Alwan, A. (2014). Prostitusi Online Dilihat Dari Instrumen Hukum Undang-Undang Nomor 11 Tahun 2008 Tentang Informasi dan Transaksi Elektronik. Jurnal Mahupiki, 2(1).

Imam, K., Kalo, S., Syahrin, A., \& Marlina, M. Pertanggungjawaban Pidana Bagi Pelaku Tindak Pidana Prostitusi Online Di Tinjau Dari Undang-Undang Nomor 11 tahun 2008 Tentang Informasi Dan Transaksi Elektronik (Studi Putusan Nomor 267/Pid. B/2015/PN. Pgp). USU LAW JOURNAL, 6(3), 95-109.

Maulidya, R. (2017). Pertanggungjawaban Pidana Pekerja Seks Komersial Dalam Tindak Pidana Prostitusi Secara Online Berdasarkan Undang Undang Nomor 11 Tahun 2008 Tentang Informasi Dan Transaksi Elektronik Di Polresta Pekanbaru. Jurnal Online Mahasiswa (JOM) Bidang Ilmu Hukum, 3(2), 1-15.

Pradana, A. M. (2015). Tinjauan Hukum Pidana Terhadap Prostitusi dan Pertanggungjawaban Pidana Para Pihak yang Terlibat dalam Prostitusi. Jurnal Hukum E Pembangunan, 45(2), 276-307. 
Raharjo, M., \& Mulyadi, L. (2017). Penerapan Sanksi Pidana Terhadap Pelaku Prostitusi Online Di Yogyakarta. Kajian Hasil Penelitian Hukum, 1(2), 16-26.

Silaban, F. E. S., Erwina, L., \& Mulyadi, M. (2013). Kebijakan Hukum Pidana Terhadap Pengaturan Tindak Pidana Narkotika Di Indonesia. Jurnal Mahupiki, 1(1).

Suendra, D. L. O. (2015). Pertanggungjawaban Pidana Koperasi dalam Tindak Pidana Melakukan Kegiatan Perbankan tanpa Ijin. Jurnal Magister Hukum Udayana (Udayana Master Law Journal), 4(2).

Wirasasmita, E. A. (2018). Pertanggung Jawaban Pidana terhadap Perawat Maternitas yang Menghilangkan Identitas Seorang Bayi di Rumah Sakit. Jurnal Magister Hukum Udayana (Udayana Master Law Journal), 7(2), 177-189.

Wirya, A. (2015). Kebijakan Formulasi Hukum Pidana Dalam Penanggulangan Tindak Pidana Kehutanan. Jurnal IUS Kajian Hukum dan Keadilan, 3(1).

\section{Website resmi}

Indonesia, CNN, (2019). Vanessa Angel Jadi Tersangka Kasus Prostitusi Online. Url:https:// www.cnnindonesia.com/nasional/20190116163019-12

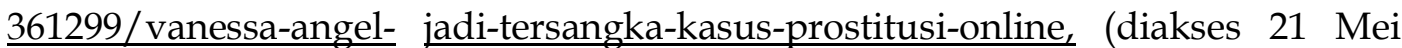
2019) 